\title{
Protective Role of Spermidine on two Tomato Cultivars against Cold-Induced Lipid Peroxidation by Enhancing Capacity of Anti-Oxidative System
}

\author{
Salwa A.Orabi ${ }^{1}$, S.R. Salman ${ }^{2}$, Faida A. Sharara ${ }^{1}$ and S.D. Abou-Hussein ${ }^{2}$
}

${ }^{1}$ Botany Dept., and ${ }^{2}$ Vegetable Research Dept., Agricultural \& Biological Research Division, National Research Centre (NRC), 33 El-Buhouth St., 12622 Dokki, Giza, Egypt.

Received: 20 Oct. 2020 / Accepted 05 Dec. 2020 / Publication date: 15 Dec. 2020

\begin{abstract}
Two pot experiments were conducted during two growing seasons 2015/2016 and 2016/2017 at the green house of the National Research Centre, Dokki, Giza, Egypt to study the effect of spermidine (Spd) on growth parameters, SPAD values, antioxidant enzymes, malondialdehyde (MDA), as well as fruits yield quantity and quality (total soluble solids (TSS) and ascorbic acid (AsA)) of two tomato cultivars (Strain B and Florida) grown under low temperature conditions. All treatments almostly caused significant increases in growth parameters and SPAD values of the two tomato cultivars relative to corresponding control plants. Moreover all Spd treatments caused marked decreases in MDA and methylglyoxal (MG) values accompanied by significant increases in APX, PAL and Gly I activities relative to control plants. All treatments almostly caused significant increases in fruits yield (g/plant) as well as TSS and AsA of fruit juices of the two tomato cultivars relative to control plants. It is worthy to mention that the highest recorded values were obtained in plants treated with $50 \mathrm{mg} / \mathrm{L}$ spermidine, these results hold true for both cultivars. Based on the obtained results, it could be concluded that the protection mechanism with Spd had helped the plants to increase their tolerance against low temperature stress, through mainly the decrease in membrane damage symptoms leading to intercellular osmotic adjustment.
\end{abstract}

Keywords: Low temperature, Antioxidant enzymes, Lipid peroxidation, spermidine, MG

\section{Introduction}

Low temperature (LT) is considered to be one of the major abiotic stresses, it causes physiological and metabolic disorder resulting in reduction of growth and productivity, reduced stomatal conductance, photosynthetic efficiency, changes in protein structure and enzyme activities (Prasad et al., 1994). Under LT stress there will be inhibition of photochemistry efficiency leading to over generation of reactive oxygen species (ROS) (Orabi, 2004; Orabi et al., 2010, 2014, 2017 , 2018 ; ; Abd El-Razek et al., 2019) which may include singlet oxygen (1O2), superoxide anion (O2,'), hydrogen peroxide (H2O2), and hydroxyl radical (OH,) (Gill and Tuteja, 2010). Under prolonged stress excess levels of ROS are produced and caused cell membrane lipid peroxidation (Ahmed et al., 2009,2010; Hussein and Orabi, 2008; Hussin et al., 2009;Mekki et al., 2010; Abd El-Motty and Orabi, 2013; Abd Elhamid et al., 2016; Orabi and Abdelhamid, 2016) beside protein denaturation, carbohydrate oxidation, photosynthetic pigment breakdown, impaired enzyme activity, damage to nucleic acids and programmed cell death (Bose et al.,2014). Therefore, plants need a delicate balance between ROS generation and scavenging(Mekki and Orabi, 2007; Orabi and Mekki, 2008; Kassab et al., 2012; Orabi et al., 2013, 2016, 2017

Tomato (Lycopersicon esculentum L.) is a member of the Solanaceae family, it is considered as one of the most important vegetables grown in Egypt. It is used as a fresh vegetable beside its importance as a raw material for agricultural industry. Also it is a rich source of lycopene, vitamins and minerals. Lycopene is responsible for the characteristic deep red color of ripe tomato fruits and tomato products (Helyes et al., 2009). Lycopene may help to counteract the harmful effects of substances called "free radicals" and different types of cancer, it is a key intermediate in the biosynthesis of many important carotenoids, such as beta-carotene and xanthophylls (DeStefani et al., 2000). Tomato plants after ecxposure to low temperature will suffer from chilling injury as a result of exposure to low, but non-freezing temperatures (ca. $>10^{\circ} \mathrm{C}$ ) (Raison and Lyons, 1986).

Corresponding Author: Salwa A. Orabi, Botany Dept., Agricultural \& Biological Research Division, National Research Centre (NRC), 33 El-Buhouth St., 12622 Dokki, Giza, Egypt.

E:mail:-dr.salwaorabi@yahoo.com 
The polyamines (PAs) are low-molecular-weight organic cations, they perform diverse biological functions (Kusano et al., 2008). Putrescine (Put.), spermidine (Spd.), and spermine (Spm.) are the most common PAs. Their levels frequently increase during stress, they have essential roles in enhancing plant stress tolerance. Acting as molecular chaperones, PAs bind to negatively charged surfaces and protect membranes and biomolecules (Kusano et al., 2008). PAs are considerd to be freeradical scavengers and activate the antioxidant enzyme machinery which help to reduce oxidative stress, membrane injury and electrolyte leakage (Kubi' s et al., 2014), acute application of PAs may cause endogenous PAs catabolism in the apoplast, which is responsible for ROS-induced oxidative damage (Di Tomaso et al., 1989). Polyamines (PAs) are aliphatic polycation compounds ubiquitously found in living organisms. PAs are usually considered to be as a new class of plant growth regulators that because their fundamental roles in physiological processes, such as protein synthesis, cell-cycle regulation, ion-channel regulation, free-radical scavenging, gene expression (Takahashi and Kakehi, 2010). Under low temperature they have protective function in LT affected plants. The polycationic PAs can combine with cellular membrane and help to avoid intracellular ice formation. PAs enhance cellular antioxidant capacity, and decrease the peroxidation of unsaturated fatty acids during LT stress. PAs improve membrane stabilization and increase the fluidity (Alcázar et al., 2010).

\section{Materials and Methods}

Two pot experiments were carried out in the greenhouse of the National Research Centre, Giza, Egypt during two successive growth seasons (2015/2016 and 2016/2017) to study the effect of foliar application of different concentrations of spermidine $(25,50$ and $100 \mathrm{mg} / \mathrm{L})$ on growth, fruit yield quantity and quality of two tomato cultivars (Strain B and Florida) grown under low temperature conditions. Seedlings (one true leaf stage) were transplanted carefully in $40 \mathrm{~cm}$ diameter pots (2seedlings /pot) at last week of November during two successive seasons. During this experiment, plants are subjected to low temperature where level of night temperature drops several times below $10{ }^{\circ} \mathrm{C}$. Each pot filled with $13 \mathrm{~kg}$ of a mixture of loam clay soil and sand soil at the ratio of $1: 1(\mathrm{w} / \mathrm{w})$ mixed with $6.7 \mathrm{~g}$ of super phosphate and $3.25 \mathrm{~g}$ of ammonium nitrate. The plants were supplied with water according to their requirements which was governed by climatic conditions. Each pot received $3.25 \mathrm{~g}$ ammonium nitrate weekly for a period of 4 weeks. The pots were arranged in complete randomized block design with three replicates for each treatment. The replicates were represented by five pots. The treatments were three levels of spermidine $(\mathrm{Spd} 1: 25 \mathrm{mg} / \mathrm{L}, \quad \mathrm{Spd} 2: 50 \mathrm{mg} / \mathrm{L}$, Spd3:100mg/L) which applied exogenously on plants after 15 and 30 days from transplanting, while the control plants were sprayed with distilled water.

\section{Growth Criteria Determination:}

Random samples of plants were collected at 75 days after transplanting from each treatment to determine some growth parameters (plant height, leaves number / plant, fresh and dry weights of leaves and root/plant) as well as determination of antioxidant enzymes, total cholorophyll (SPAD values), methylglyoxal and malondialdehyde levels. At harvest, tomato fruits were collected weekly and total yield was calculated as $\mathrm{g} /$ plant. Fruit quality i.e. total soluble solids (TSS) and vitamin c of fruit juice were determined.

\section{Biochemical Constituents Determination:}

Extraction of the antioxidant enzyme ascorbate peroxidase (APX) was that of Mukherjee and Choudhuri (1983). The activity of APX (EC1.11.1.11) was determined according to Nakano and Asada (1981). One unit of APX was defined as the amount of enzyme that breaks down $1 \mu$ mol of ascorbate per min. The extraction and assay of phenylalanine ammonia lyase (PAL, EC 4.3.1.5) was estimated according to the method adopted by Beaudoin-Egan and Thrope (1985). The activity of PAL is defined as the amount of enzyme forming $1 \mathrm{mmol}$ of transcinnamic acid from the substrate phenylalanine per min. Glyoxalase I (Gly I, EC: 4.4.1.5) activity was measured following Hasanuzzaman et al., (2011). Chlorophyll was determined using chlorophyll meter (Model: TYS-A, Zhe Jang Top Instrument Co. LTD., Hangzhou, China). Methylglyoxal Level (Mg) was measured after the formation of the product N- $\alpha$-acetyl-S-(1-hydroxy-2-oxo-prop-1-yl) cysteine following (Wild 
et al., 2012). Lipid peroxidation was determined by measuring Malondialdehyde (MDA) content as described by Dhindsa et al., (1982).

Ascorbic acid (AsA) was determined using phenol indophenols dye method (A.O.A.C., 1990) Total soluble solids (TSS) were determined using a portable refractometer (Brixstix BX $100 \mathrm{Hs}$; Technique Corporation, Livermore, CA).

\section{Statistical Analysis:}

The data obtained were subjected to standard analysis of variance procedure according to Snedecor and Cochran (1980). The values of L.S.D. were calculated whenever F values were significant at $5 \%$ level.

\section{Results and Discussions}

\section{Effect on vegetative growth:}

Data recorded on vegetative growth traits i.e. plant height, leaves number /plant, fresh and dry weights of leaves and root/plant as affected by spermidine. Florida cultivar was characterized by higher significant increases in these growth parameters than those of Strain B cultivar under all treatments (Table 1). Spd at $50 \mathrm{mg} / \mathrm{L}$ caused the highest significant increases in the growth parameters of the two tomato cultivars followed by $100 \mathrm{mg} / \mathrm{L}$. Parallel to these results of spermidine treatments as one of the PAs. Abd El Wahed and Gamal El Din (2004) mentioned that spermidine, stimulated vegetative growth characters of chamomile plants. Also, putrescine enhanced the growth (fresh and dry weight) of mentha pipeprita (Youssef et al., 2002). Putrescine significantly promoted vegetative growth characters in addition to significant increases in dry matter contents of geranium occurred in the two cuttings (Ayad et al., 2010) and Jojoba plants (Taha et al., 2015). Moreover, Abd El- Monem (2007) found that foliar application of various concentrations of putrescine at 30 DAS induced a marked significant reduction in shoot length when the samples were harvested at 75 days old plants as compared with similar treatments sprayed at 60 DAS. In addition, Orabi et al., (2015) reported that spermine treatments significantly promoted plant height, fresh and dry mass (g/plant) of Cymbopogon citratus L., especially $100 \mathrm{mg} / 1$ spermine which mostly recorded the highest increments in total nitrogen, total phosphorous and total potassium, mainly in the second cut. Polyamines play an important role in flower initiation and development, fruit setting and ripening and they are essential when plants are exposed to stress (Pathak et al., 2014).

Table 1: Effect of spermidine on some growth parameters of two tomato cultivars grown under low temperature conditions

\begin{tabular}{|c|c|c|c|c|c|c|}
\hline \multirow{2}{*}{ Treatments } & \multicolumn{2}{|c|}{ Plant height(cm) } & \multicolumn{2}{|c|}{ Number of leaves } & \multicolumn{2}{|c|}{ Leaves fresh weight (g) } \\
\hline & Strain B cv. & Florida cv. & Strain B cv. & Florida cv. & Strain B cv. & Florida cv. \\
\hline Control & 43.00 & 52.69 & 16.33 & 20.00 & 44.57 & 60.21 \\
\hline SPd1 25mg/L & 50.33 & 56.50 & 20.67 & 26.33 & 51.46 & 65.14 \\
\hline SPd2 50mg/L & 55.67 & 61.00 & 25.33 & 31.67 & 59.11 & 74.22 \\
\hline $\mathrm{SPd} 3100 \mathrm{mg} / \mathrm{L}$ & 53.33 & 57.67 & 22.67 & 29.33 & 56.09 & 71.31 \\
\hline L.S.D 5\% & \multicolumn{2}{|c|}{4.58} & \multicolumn{2}{|c|}{2.70} & \multicolumn{2}{|c|}{7.01} \\
\hline
\end{tabular}

Table 1: Cont.

\begin{tabular}{lcccccc}
\hline \multirow{2}{*}{ Treatments } & \multicolumn{2}{c}{ Leaves dry weight (g) } & \multicolumn{2}{c}{ Root fresh weight (g) } & \multicolumn{2}{c}{ Root dry weight (g) } \\
\cline { 2 - 7 } Control & Strain B cv. & Florida cv. & Strain B cv. & Florida cv. & Strain B cv. & Florida cv. \\
SPd1 25mg/L & 6.01 & 7.68 & 18.40 & 21.90 & 6.76 & 7.88 \\
SPd2 50mg/L & 7.12 & 8.63 & 20.16 & 25.67 & 7.96 & 9.99 \\
SPd3 100mg/L & 8.31 & 10.22 & 24.81 & 27.42 & 10.04 & 12.64 \\
L.S.D 5\% & 7.88 & 9.88 & 24.09 & 26.00 & 9.93 & 11.97 \\
\hline
\end{tabular}

\section{Effect on biochemical traits:}

Florida cultivar was characterized by higher activititis of APX, PAL and Gly I than Strain B cultivar either in treated or untreated plants (Table 2). All SPd treatments mostly led to significant 
increases in all studied antioxidant enzymes (APX, PAL \& Gly I). Meanwhile, significant decrements were obtained in MG and MDA with most of the applied treatments.

However scientists working on polyamines found that polyamines mostly increased the activities of the antioxidant enzymes such as SOD, CAT, POX, APX, GR and PAL in plants under stress (Nasibi et al., 2011; Shallan et al., 2012; Orabi et al., 2015,2016,2017, 2020 ). It was also reported that application of polyamines could effectively scavenge $\mathrm{O}_{2}^{-}$generated in both enzymatic and chemical cell-free systems and could inhibit the production of $\mathrm{O}_{2}^{-}$by the superoxide-dependent conversion of 1-amino-cyclo-propane-1-carboxylic acid and that led to ethylene (Bors et al., 1989). Polyamines could act as free radical scavenger (Nayyar and Chender, 2004) leading to obvious reduction in MDA contents (Orabi and Abou Hussein 2019a, )

Increase of MG toxicity in LT affected plants was reversed by Spd treatment (Nahar et al., 2015) working on mung bean, that because the enhanced activities of the glyoxalase enzymes and increased GSH level after Spd pretreatment leading to reduction of lipid peroxidation represented by MDA.

APXs enzymes involved in scavenging $\mathrm{H}_{2} \mathrm{O}_{2}$ in water-water and AsA-GSH cycles using AsA as the substrate, to catalyz the transfer of electrons from AsA to $\mathrm{H}_{2} \mathrm{O}_{2}$, to produc DHA and water (Pang and Wang 2010) . Phenylalanine ammonia-lyase (PAL) catalyzes the transformation by deamination of Lphenylalanine into trans-cinnamic acid, which is the prime intermediary in the biosynthesis of phenolics (Levine et al., 1994).

Methylglyoxal (MG) is a highly cytotoxic compound that causes protein and DNA degradation. MG disrupts the antioxidant machinery and act as mediator for $\mathrm{O} \bullet-2$ generation, causing an oxidative burst (Yadav et al., 2005). Gly I, participates to catalyze the detoxification reaction of MG to Dlactate. Gly I converts MG to SLG utilizing GSH (Yadav et al., 2005).

Under environmental stresses including LT stress reduction of chl biosynthesis and rapid degradation of chl are common occurrence (Mohanty et al., 2006). Seedlings pretreated with Spd recovered the reduction of total $\mathrm{chl}(\mathrm{a}+\mathrm{b})$ by increasing its content under LT stress (Nahar el al., 2015). PAs prevent stress-induced loss of protein and enzymes, and protects chloroplasts and photosynthetic pigments (Graziano et al., 2002) resulting in reduction of the lipid peroxidation.

Table 2: Effect of spermidine on Spad values, some antioxidant enzyme activities, methylglyoxal (MG) and malondialdehyde (MDA) levels of two tomato cultivars grown under low temperature conditions

\begin{tabular}{|c|c|c|c|c|c|c|}
\hline \multirow{3}{*}{ Treatments } & \multirow{2}{*}{\multicolumn{2}{|c|}{\begin{tabular}{|c|} 
Total chlorophyll \\
(Spad units)
\end{tabular}}} & \multicolumn{2}{|c|}{ APX } & \multicolumn{2}{|c|}{ PAL } \\
\hline & & & \multirow[b]{2}{*}{ Strain B cv. } & \multicolumn{2}{|c|}{ ( $\mu$ mole /g fresh weight) } & \multirow[b]{2}{*}{ Florida cv. } \\
\hline & Strain B cv. & Florida cv. & & Florida cv. & Strain B cv. & \\
\hline Control & 33.30 & 35.50 & 5.11 & 6.23 & 28.34 & 32.13 \\
\hline SPd1 25mg/L & 35.20 & 36.90 & 5.78 & 7.33 & 32.11 & 34.50 \\
\hline SPd2 50mg/L & 37.00 & 39.30 & 7.71 & 9.20 & 34.30 & 38.02 \\
\hline SPd3 100mg/L & 36.00 & 38.30 & 6.88 & 8.44 & 33.18 & 35.49 \\
\hline L.S.D 5\% & \multicolumn{2}{|c|}{1.76} & \multicolumn{2}{|c|}{0.42} & \multicolumn{2}{|c|}{3.01} \\
\hline
\end{tabular}

Table 2: cont.

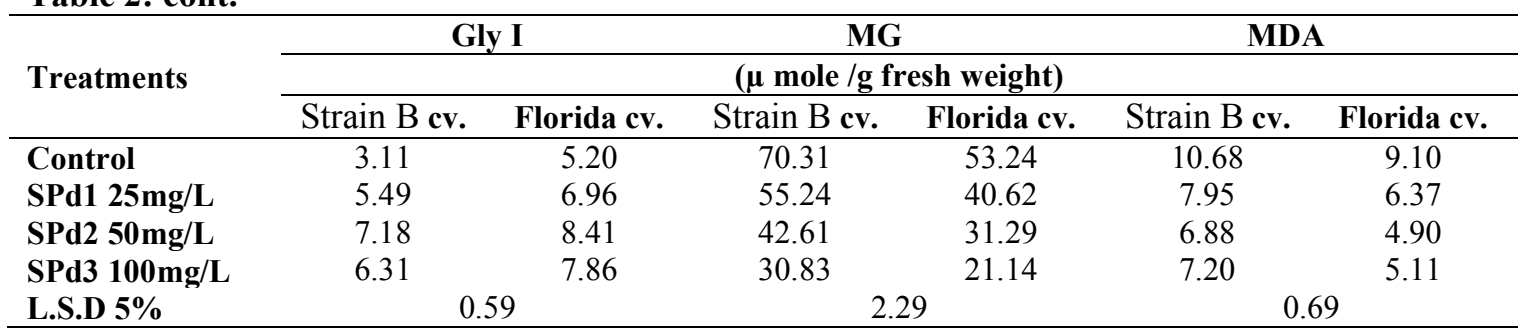

\section{Effect on fruits yield and fruits quality:}

Florida cultivar was characterized by almostly significant increases in fruits yield (g/plant) and fruits quality than Strain B cultivar under all treatments (Table 3). SPd treatment at $50 \mathrm{mg} / \mathrm{L}$ caused the highest significant increase in the yield, TSS and AsA of both tomato cultivars followed by SPd treatment at $100 \mathrm{mg} / \mathrm{L}$ 
These increments in yield components due to spermidine treatments may be attributed to the increase in growth rate. In this regard, Davis (1995) reported that polyamines play a critical role in different biological processes, including cell division, growth, somatic embryogenesis, floral initiation, development of flowers and fruits.

Our obtained data of spermidine treatments agreed with those reported by El-Tohamy et al (2012) who found that the higher level of Putrescine significantly increased yield of Cape gooseberry. Putrescine up to $100 \mathrm{mg} \mathrm{L-1}$ significantly increased the chickpea yield criteria (number of branches, pods and seeds/ plant, seed and straw yield/ plant and/ fed and biological yield/ fed (Amin et al., 2013). Orabi et al., $\left(2017^{\mathrm{b}}, 2020\right)$ recorded yield increments in yield traits by using putracine on orange trees and spermine on canola plants respectively.

Fruits of florida cultivar were characterized by significant increases in the TSS and AsA than fruits of Strain B cultivar (Table 3). TSS values associated with taste and had significant indication for improvement in yield quality as reported by Vural et al., (2000). Alsokari (2011) stated that, spermine treatment increased total soluble sugars, polysaccharides and carbohydrates contents of Vigna sinensis. Additionally, Li et al., (2014), under water stress found that white clover plants treated with spermidine exhibited more accumulated organic solutes including soluble sugar, reducing sugar, betaine and free proline. Under new reclaimed soil conditions putrescine treatments recorded higher levels of TSS in Valencia orange trees leaves (Orabi et al., 2017 ). Nahar et al. (2015) mentioned that exogenous Spd pretreatment reduced the oxidative stress by decreasing $\mathrm{H} 2 \mathrm{O} 2$ content and lipid peroxidation where One of the primary indicators of LT stress was oxidative damage. Polyamine increased AsA content, decreased DHA levels, increased AsA/DHA ratio, increased GSH levels, decreased GSSG levels, and increased GSH/GSSG ratios in grapevine leaf tissues (Ikbal et al., 2014). Ascorbate is a vital water-soluble antioxidant of plant cell reacting with a range of ROS including $\mathrm{H}_{2} \mathrm{O}_{2}, \mathrm{O}_{2}$,' and 1O2. AsA also scavenges $\mathrm{OH}$, at diffusion-controlled rates (Smirnoff, 2005). By MDHAR and DHAR AsA is regenerated from DHA, electron donors here are NADPH and GSH, respectively (Gill and Tuteja, 2010; Orabi and El-Noemani 2015). Its correlation with oxidative stress protection of photosynthetic apparatus, enhancement of PSII quantum yield in grapevine plants that improved photosynthesis and plant growth (Ikbal et al., 2014).

Table 3: Effect of spermidine on fruit yield, total soluble solids and ascorbic acid of two tomato cultivars grown under low temperature conditions

\begin{tabular}{lcccccc}
\hline \multirow{2}{*}{ Treatments } & \multicolumn{2}{c}{ Fruit yield g/plant } & \multicolumn{2}{c}{ Total soluble solids\% } & \multicolumn{2}{c}{ AsA mg/100ml } \\
\cline { 2 - 7 } & $\begin{array}{c}\text { Strain B } \\
\text { cv. }\end{array}$ & Florida cv. & $\begin{array}{c}\text { Strain B } \\
\text { cv. }\end{array}$ & Florida cv. & $\begin{array}{c}\text { Strain B } \\
\text { cv. }\end{array}$ & Florida cv. \\
\hline Control & 391.80 & 430.50 & 4.18 & 4.49 & 31.05 & 37.41 \\
SPd1 25mg/L & 565.22 & 622.14 & 4.76 & 4.93 & 33.87 & 39.11 \\
SPd2 50mg/L & 722.00 & 835.24 & 5.11 & 5.88 & 41.56 & 47.77 \\
SPd3 100mg/L & 589.32 & 716.96 & 4.97 & 5.16 & 35.63 & 42.38 \\
L.S.D 5\% & \multicolumn{2}{c}{64.30} & \multicolumn{2}{c}{0.34} & \multicolumn{2}{c}{6.53} \\
\hline
\end{tabular}

\section{Conclusion:}

It could be concluded that when tomato plants grown under low temperature and foliar treated with Spd after transplanting, could alleviate the harmful impacts of low temperature through the enhancement of their protective parameters, such as antioxidant enzymes activity and AsA to play vital roles in reducing Mg toxicity and lipid peroxidation. Reduction of ROS by SPd were manifested on the levels of biomembranes and biomolecules protection leading finally to reduction of oxidative damage in tomato plants under cold stress.

\section{References}

A.O.A.C., 1990. Association of Official Agriculture chemist. Official methods of Analysis 9th pp. 490-510 - Ef., Benjamin Firmin Station, Washington, D.C.Z.

Abd El Wahed, M.S.A and K.M. Gamal El Din, 2004.Stimulation of growth, flowering and biochemical constituents of chamomile plant (Chamomilla recutita L., Rausch) with spermidine and stigmasterol application. Egypt. J. Hort. 31: 45-58. 
Abd Elhamid, E.M., S.A. Orabi and M.Sh. Sadak, 2016. Physiological responses of grain soaking with Aspirin on two cultivars of wheat plant. International Journal of ChemTech Research, 9(9): 124-131.

Abd El-Monem, Amany A., 2007. Polyamines as modulators of wheat growth, metabolism and reproductive development under high temperature stress. Ph.D. Thesis, Ain Shamas Univ., Cairo, Egypt.

Abd El-Motty, E.Z. and S.A. Orabi, 2013. The Beneficial Effects of Using Zinc, Yeast and Selenium on Yield, Fruit Quality and Antioxidant Defense Systems in Navel Orange Trees Grown under Newly Reclaimed Sandy Soil. J. App. Sci. Res., 9(10): 6487-6497.

Abd El-Razek, E., E.Z. Abd El-Motty, S.A. Orabi and A. Abou-Elfotouh, 2019. Improving Fruit Quality of Mango Fruits cv. Zebda by Coating with Moringa and Green Tea Leaves Extracts under cold Storage. Middle East J. Agric. Res., 8(4): 1325-1343

Ahmed, A.G., S.A. Orabi and A.M. Gomaa, 2009. Physiological effects of bio-organic farmingongrowth parameters, yield and antioxidant enzymes activity of grain sorghum. J. Egyptian Journal of Agronomy, 31 (2): 237-252.

Ahmed, A. G., M.A. Bekheta, and S.A. Orabi, 2010. Influence of arginine on growth and productivity of two sorghum cultivars grown under water shortage. International J. of Acadmic Res., 1:7280.

Alcázar, R., T. Altabella, F. Marco, C. Bortolotti, M. Reymond, C. Koncz, P. Carrasco, and A.F. Tiburcio, 2010. Polyamines Molecules with regulatory functions in plant abiotic stress tolerance. Planta. 231: 1237-1249.

Alsokari, S.S., 2011. Synergistic effect of kinetin and spermine on some physiological aspects of seawater stressed Vigna sinensis plants. Saudi Journal of Biological Sciences, 18: 37-44

Amin, A.A., F.A. Gharib, H.F. Abouziena and M.G. Dawood, 2013. Role of I ndole - 3 - butyric and or/ and putrescine in Improving productivity of chickpea (Cicer arientinum L.). Plants. Pakistan J. of Biol. Sci. 16 (24): 1894-1903.

Ayad, H.S, F. Reda and M.S.A. Abdalla, 2010. Effect of putrescine and zinc on vegetative growth, photosynthetic pigments, lipid peroxidation and essential oil content of Geranium (Pelargonium gravealens L.) world J. of Agric. Sci. 6(5): 601-608.

Beaudoin-Egan, L. and T. Thrope, 1985. Tyrosine and phenylalanine ammonialyase activities during shoots inhibition in tobacco callus cultures. Plant Physiol. 78: 438-441.

Bors, W., C., Langebartels, C., Michel, and H.Jr., Sandermann, 1989. Polyamines as radical scavengers and protectansagainst ozono damage. Phytochemistry, 28: 1589-1595.

Bose, J., Rodrigo-Moreno, A., Shabala, S, 2014. ROS homeostasis in halophytes in the context of salinity stress tolerance. J. Exp. Bot. 65: 1241-1257.

Davis, P.J., 1995. Plant hormones: physiology and biochemistry and biology P. 159 Kluwer academic publishers, London.

DeStefani, E., F. Oreggia, and P. Boffetta, 2000. Tomatoes, tomato-rich foods, lycopene and cancer of the upper aero digestive tract: A case control in Uruguay. Oral Oncol., 36: 47-53.

Dhindsa, R.S., P. Plumb-Dhindsa, and D.M. Reid, 1982. Leaf senescence and Lipid peroxidation. Effects of some phytohormones and scavengers of free radicals and singlet oxygen. Physiol. Plant, 56: 453-457.

Di Tomaso, J.M., J.E. Shaff, and L.V. Kochian, 1989. Putrescineinduced wounding and its effects on membrane integrity and ion transport processes in roots of intact corn seedlings. J. Plant Physiol. 90, 988-995.

El-Tohamy, W.A., H.M. EL-Abagy, M.A. Badr, A.A. Ghoname and S.D. Abou-Hussein, 2012. Improvement of productivity and quality of cape gooseberry (Physalis peruvianal.) by foliar application of some chemical substances. J. Applied Sci. Res. 8: 2366-2370.

Gill, S.S., N. Tuteja, 2010. Reactive oxygen species and antioxidant machinery in abiotic stress tolerance in crop plants. Plant Physiol. Biochem., 48: 909-930.

Graziano, M., M.V. Beligni, and L. Lamattina, 2002. Nitric oxide improves internal iron availability in plants. Plan Physiol. 130, 1852-1859.

Hasanuzzaman, M., M.A. Hossain, and M. Fujita, 2011. Nitric oxide modulates antioxidant defense and the methylglyoxal detoxification system and reduces salinity-induced damage of wheat seedlings. Plant Biotechnol. Rep. 5: 353-365. 
Helyes, L., A. Lugasi, A. Pogonyi, and Z. Pek, 2009. Effect of variety and grafting on lycopene content of tomato (Lycopersicon lycopersicum L. karsten) fruit. Acta Alimentaria, 38: 27-34.

Hussein, M.M. and S.A. Orabi, 2008. Growth and antioxidant enzymes activity in onion plants as affected by thiamine and salinity. Plant Nutrient Management under stress conditions $17^{\text {th }}$ International symposium of CIEC: 261-278.

Hussein, M.M., M.A. Bakheta and S.A. Orabi, 2009. Influence of abscisic acid and benzyl adenine on some growth characters, endogenous hormones and some chemical constituents of cotton plants grown under drought stress. Egyptian Journal of Agronomy, 31: 253-270.

Ikbal, F.E., J.A. Hernández, G. Barba-Espín, T. Koussa, A. Aziz, M. Faize, et al., 2014. Enhanced salt-induced antioxidative responses involve a contribution of polyamine biosynthesis in grapevine plants. J. Plant Physiol., 171: 779-788.

Kassab, O.M., S.A. Orabi, and A.A. Abo Ellil, 2012. Physiological response to potassium application in fodder beet plant grown under water stress. Australian J. of Basic and Applied Sciences, 6(13):566-574.

Kubi' s, J., J. Floryszak-Wieczorek, and M. Arasimowicz-Jelonek, 2014. Polyamines induce adaptive responses in water deficit stressed cucumber roots. J. Plant Res. 127, 151-158.

Kusano, T., Berberich, T., Tateda, C., and Takahashi, Y, 2008. Polyamines: essential factors for growth and survival. Planta, 228: 367-381.

Levine, A., R. Tenhaken, R. Dixon, and C. Lamb, 1994. $\mathrm{H}_{2} \mathrm{O}_{2}$ from the oxidative burst orchestrates the plant hypersensitive discase resustance response. Cell, 79: 583-593.

Li, Z.,Y. Peng, X.-Q. Zhang, M.-H. Pan, X. Ma, L.-K. Huang and Y.-H. Yan, 2014. Exogenous spermidine improves water stress tolerance of white clover (Trifolium repenc L.) involved in antioxidant defence, gene expression and proline metabolism. POJ., 7(6):517-526.

Mekki, B.B. and S.A. Orabi, 2007. Response of prickly oil lettuce (Lactuca scariola L.) to uniconazole and irrigation with diluted seawater, Am-Euras J Agric Environ Sci., 2: 611-618

Mekki, B.B., JA.DA. Silva, and S.A. Orabi. 2010. Yield fatty acide and antioxidant enzymes of two canola (Brassica napus L.) cultivars in response to stigmasterol.Afr. J. plant Sci. Biotechnol.4:28035

Mohanty, S., Grimm, B., Tripathy, B.C, 2006. Light and dark modulation of chlorophyll biosynthetic genes in response to temperature. Planta. 224: 692-699.

Mukherjee, S.P., and M.A. Choudhuri, 1983. Implication of water stress-induced changes in the levels of endogenous ascorbic acid and hydrogen peroxide in vigna seedling. Physiol. Plant., 58: 166- 170.

Nahar, K., M. Hasanuzzaman, M.M. Alam, and M. Fujita, 2015. Exogenous Spermidine Alleviates Low TemperatureInjury in Mung Bean (Vigna radiata L.) Seedlings by Modulating AscorbateGlutathione and Glyoxalase Pathway. Int. J. Mol. Sci., 16: 30117-30132.

Nakano, Y., and K. Asada, 1981. Hydrogen Peroxide is scavenged by ascorbate-specific peroxidase in spinach chloroplasts. Plant and Cell Physiol., 22: 867-880.

Nasibi, F., M. Yaghoobi and K.H., Kalantari, 2011. Effect of exogenous arginine on alleviation of oxidative damage in tomato plant under water stress. Journal of Plant Interactions. 6: 291-296

Nayyar, H., and S. Chander, 2004. Protective effects of polyamines against oxidative stress induced by water and cold stress in chickpea. J. Agron. Crop Sci., 190:355-365.

Orabi, S.A. and Mekki B.B. 2008. Root yield and quality of sugar beet (Beta vulgaris L.) in response to ascorbic acid and saline irrigation water. American-Eurasian J. Agric. \& environ. Sci., 4(4):504-513.

Orabi, S.A., M.M. Hussein., S.S. Zaki, and F.A. Sharara, 2018b. Influence of hydrogen peroxide on growth, yield and biochemical constituents of canola plants grown under different irrigation interval. Curr. Sci. Int., 7(3):407-418.

Orabi, S. A., B.B. Mekki, and F.A., Sharara, 2013. Alleviation of adverse effects of salt stress on fababean (Vicia faba L.) plants by exogenous application of salicylic acid. World Appl Sci., J. 27 (4): 418-427.

Orabi, S.A., E.Z. Abd El-Motty and I.M. Talaat, 2017b. Influence of arginine and putrescine on yield, quality and antioxidant defense systems in orange trees cv Valencia grown in Nubaria. Bull.NRC, 9:169-186. 
Orabi, S.A. and S.D. Abou-Hussein, 2019a. Alleviation of oxidative stress in plants subjected to extreme temperatures. A review. Curr. Sci. Int., 8(2): 307-320.

Orabi, S.A and S.D. Abou-Hussein, 2019b. Antioxidant defense mechanisms enhance oxidative stress tolerance in plants. A review. Curr. Sci. Int., 8(3): 565-576.

Orabi, S.A. and A.S.A. El-Noemani, 2015. Role of proline in improving drought tolerance of faba bean plants via antioxidant responses to enhanced generation of superoxide anion radical and hydrogen peroxide. American-Eurasian Journal of Sustainable Agriculture, 31-43.

Orabi, S.A. and M.T. Abdelhamid, 2016. Protective role of $\alpha$-tocopherol on two Vicia faba cultivars against seawater-induced lipid peroxidation by enhancing capacity of anti-oxidative system. ournal of the Saudi Society of Agricultural Sciences., 15(2): 145-154.

Orabi, S.A., 2004. Physiological impacts of cold injury on cucumber (Cucumis stivus L.) plant Ph.D. Thesis, Fac. of Sci., Cairo, Univ., Egypt.

Orabi, S.A., E.Z. Abd El-Motty, M.S. El-Shamma, S.D. Abou-Hussein and F.A. Sharara, 2018a. The effect of Salicylic acid and Aspirin Treatments on Enzymes Activity and Fruit Quality of Clementine Mandarin Fruits during Different Cold Storage Periods. Middle East J. Agric. Res., 7(2):583-593.

Orabi, S.A., F.A. Sharara and I.M. Talaat, 2016. Effect of putrescine and pyridoxine (vitamin B6) on the antioxidant defense systems and free radical scavenging activity in canola plants. International Journal of Pharm Tech Research, 9:1-8.

Orabi, S.A., I.M. Talaat and L.K. Balbaa, 2014. Physiological and Biochemical responses of thyme plants to some antioxidants. Nusantatra bioscience, 6(2):118-125.

Orabi, S.A., I.M. Talaat, L.K. Balbaa and A.E. Abdalla, 2015. Influence of pyridoxine and spermine on lemongrass (Cymbopogon citratus) plants. Nusantara Bioscience, 7: 139-143.

Orabi, S.A., M.M. Hussein, E.Z. Abd El-Motty, and S.Y. El-Faham, 2018c. Effect of AlphaTochopherol andGlutamic Acid on Total Phenols, Antioxidant Activity, Yield and Fruit Properties of Mango Trees. Middle East J. Appl. Sci., 8(4): 1229-1239.

Orabi, S.A., S.D. Abou-Hussein and F.A. Sharara, 2017a. Role of Hydrogen peroxide and $\alpha$ tocopherol in alleviating the harmful effect of low temperature on cucumber (Cucumis sativas $\mathrm{L}$.) plants. Middle East J. Appl. Sci., 7(04):914-926.

Orabi, S.A., S.R. Salman and M.A.F. Shalaby, 2010. Increasing resistance to oxidative damage incucumber (Cucumis sativus L.) plants by exogenous application of salicylic acid and paclobutrazol. World J. of Agri. Sci., 6: 252-259.

Orabi, S.A., T.A. El-Shahawy and F.A. Sharara, 2017c. The compensatory effect of glutathione on alleviating salinity - induced modulations in growth and biochemical traits in maize irrigated with diluted seawater. Agric EngInt: CIGR J, 19(5): 80-90.

Orabi, S.A., T.A. El-Shahawy and F.A. Sharara, 2020. The polyamine spermine in retarding salinityinduced stress in canola.Middle East J. Appl. Sci., 10(1): 86-100.

Pang, C.H. and B.S. Wang, 2010. Role of ascorbate peroxidase and glutathione reductase in Ascorbate- Glutathione cycle and stress tolerance in plants. In: Anjum NA, Chan MT, Umar S (eds) Ascorbate-Glutathione pathway and stress tolerance in plants. Springer, Dordrecht, pp $91-112$

Pathak, M.R., J.A. Teixeira da Silva and S.H., Wani, 2014. Polyamines in response to abiotic stress tolerance through transgenic approaches. GM Crops Food 5, 87-96. 10.4161/gmcr.28774

Prasad, T.K., M.D. Anderson, B.A. Martin, CR. Stewart.1994. Evidence for chilling-induces oxidative stress in maize seedlings and a regulatory role for hydrogen peroxide. Plant Cell, 6:6574.

Raison, J.K., and J.M. Lyons, 1986. Chilling injury- a plea for uniform terminology. Plant Cell Environ, 9: 685-686.

Shallan, M.A., H.M.M., Hassan, A.A.M., Namich and A.A., Ibrahim, 2012. Effect of sodium, nitroprusside, putrescine and glycine betaine on alleviation of drought stress in cotton plant. Am Eurasian J. Agri. Environ., 12:1252-1265.

Smirnoff, N., 2005. Ascorbate, tocopherol and carotenoids: Metabolism, pathway engineering and functions. In Antioxidants and Reactive Oxygen Species in Plants; Smirnoff, N., Ed., Blackwell Publishing: Oxford, UK, 53-86. 
Snedecor, G.W., and W.G., Cochran, 1980. Statistical Methods. $7^{\text {th }}$ ed. Iowa State Univ. Press, Iowa, USA.

Taha, L.S., H.A.A. Taie, and M.M. Hussein, 2015. Antioxidant properties, Secondary metabolites and Growth as affected by application of putrescine and Moringa leaves extract on Jojoba plants, J.APP Pharmaceutical Sci., 5(01):030-036.

Takahashi, T., Kakehi, and J.I. Polyamines, 2010. Ubiquitous polycations with uniqueroles in growth and stressresponses. Ann. Bot. 105: 1-6.

Vural, H., D. Eşiyok, and I. Duman 2000. Vegetable Growing. Ege University, Đzmir, Turkey, 440 p.(in Turkish).

Wild, R., L. Ooi, V. Srikanth, and G. Münch, 2012. A quick, convenient and economical method for the reliable determination of methylglyoxal in millimolar concentrations: the N-acetyl- Lcysteine assay. Anal. Bioanal. Chem. 403: 2577-2581.

Yadav, S.K., S.L. Singla-Pareek, M. Ray, M.K. Reddy, and S.K. Sopory, 2005. Transgenic tobacco plants overexpressing glyoxalase enzymes resist an increase in methylglyoxal and maintain higher reduced glutathione levels under salinity stress. FEBS Lett., 579: 6265-6271.

Youssef, A.A., M.S. Aly, E.N. Abou Zeid, L. Iliey and S. Titiana, 2002.Effect of some growth substances on mass production and volatile oil yield of Mentha piperita E. "Bulgaro" Egypt. J. App. Sci., 176 (11): 610-623. 